IsaAcs, A. \& Donald, H. B. (1955). J. gen. Microbiol. 12, 241-247

\title{
Particle Counts of Haemagglutinating Viruses
}

\author{
By A. ISAACS AND HEATHER B. DONALD
}

The National Institute for Medical Research, Mill Hill, London, N.W.7

SUMMARY: The electron microscope was used to make particle counts of the viruses of Newcastle disease of fowls, fowl plague, mumps and influenza C. Two counting techniques previously described were also used, and correlations with simultaneous measurements of haemagglutination and infectivity were made.

In a previous study (Donald \& Isaacs, 1954a) counts were made in the electron microscope of influenza virus particles, and related to measurements of haemagglutination and infectivity of the preparations carried out under optimal conditions. It was found that at the agglutination end-point there was about one virus particle/red cell. It was also found that about ten virus particles of the standard influenza strains corresponded to the minimal infective dose. The particle count methods developed for that study are extended here to the related haemagglutinating viruses of Newcastle disease, fowl plague, mumps and influenza $C$. It was not always possible to use both counting techniques for each of these viruses; however, the modifications developed for each particular case and the results obtained are presented in this paper.

\section{MATERIALS AND METHODS}

Virus strains. Fowl plague-'Dutch' strain; Newcastle disease-(N.D.V.) 'Herts.' strain; mumps-Enders EMA 41 strain; influenza C-Taylor's 1233 strain (1949).

Both particle-counting techniques and the methods of biological assay were described in an earlier paper (Donald \& Isaacs, 1954 $a$ ). Certain modifications were introduced for each of the above viruses.

Preparation of virus material. With influenza C 10-day eggs were inoculated amniotically since this virus does not grow well in the allantoic eavity, and the allantoic fluid was harvested after 2 days. Dilutions of $10^{-4}$ of the seed virus were used for inoculation.

Newcastle disease and fowl plague viruses were passaged in the allantoic cavity of 10-day eggs and harvested after $18 \mathrm{hr}$. of incubation at $35^{\circ}$. A dilution of $10^{-4}$ of the seed virus was used for Newcastle disease virus, $10^{-3}$ for fowl plague.

Mumps virus was passaged in the allantois of 8-day eggs and harvested after 5 days of incubation at $35^{\circ}$. A dilution of $10^{-4}$ of the seed virus was used for inoculation.

Modifications to haemagglutination titration. Titrations with influenza $\mathrm{C}$ were carried out in the cold room $\left(+2^{\circ}\right)$ with pre-chilled reagents, as this virus elutes spontaneously from red cells at room temperature. Titrations with 
Newcastle disease virus were read immediately on settling as this virus elutes quite rapidly at room temperature.

Modifications to infectivity titration. For influenza $\mathrm{C}$ titration in the amniotic cavity was used and eggs were incubated for 3 days at $35^{\circ}$ after inoculation. Mumps virus was titrated in the allantoic cavity with incubation for 5 days after inoculation. Amniotic titration of mumps virus did not improve the sensitivity of the infectivity titration.

\section{Modifications to red cell counting technique}

Fowl plague virus. Absorptions were most successful with cells not treated with periodate and an absorption time of $15 \mathrm{~min}$. at $0^{\circ}$.

Newcastle disease virus. Maximal absorptions were obtained after $1 \mathrm{hr}$. at $0^{\circ}$ using about $2 \mathrm{ml}$. of a $10 \%$ suspension of red cells $/ \mathrm{ml}$. infected allantoic fluid. This was approximately twice the concentration required for influenza virus strains of comparable haemagglutin titre. Periodate treatment of red cell ghosts did not improve absorption.

Influenza $C$ virus. The normal absorption techniques even with extreme precautions in regard to chilled reagents and centrifugation temperature did not cause significant absorption of viral haemagglutinins. A 'cascade' process similar to that advocated by Minuse, Quilligan \& Francis (1954) was successful, however. The infected allantoic fluid was absorbed with red cells, and the supernatants absorbed with fresh red cells a number of times until the virus was satisfactorily removed. In a typical experiment using three lots of red cells and $5 \mathrm{~min}$. absorption times at $0^{\circ}$ it was possible to decrease the haemagglutination titre of a particular preparation from 1280 to less than 10 , although the same amount of cells added in a single absorption had no detectable effect on the haemagglutinin titre. It was not possible to obtain accurate particle counts with this type of absorption technique so the method was used solely as a check for the specificity of the spraying technique. The supernatant at the end of the 'cascade' process was dialysed against distilled water, mixed with polystyrene latex particles and sprayed in the usual way.

Mumps virus. A similar 'cascade' process was found to be satisfactory. Six separate absorptions of $5 \mathrm{~min}$. each at $0^{\circ}$ were necessary before $80 \%$ of the virus was absorbed. Again, this technique was used solely as a check that particles occurring in original sprayed droplets were the elementary bodies of the virus.

Modifications to spraying technique. Preparations of mumps and Newcastle disease virus were fixed with osmic acid before spraying. Fixation with $0 \cdot 1 \%$ osmic acid was found to have a deleterious effect on the elementary bodies of fowl plague virus. Unfixed preparations were therefore sprayed in an ultraviolet cabinet. For all spray counts the correlation coefficients between virus and latex particles were $\geqslant 0 \cdot 6$ with $P<0.01$.

The four viruses, fowl plague, Newcastle disease, mumps and influenza $\mathrm{C}$ will be treated separately as there were differences in applicability of the two counting techniques, and also interesting morphological differences in the particles. 


\author{
RESULTS \\ Forvl plague virus
}

Pl. 1, fig. 1 shows the results obtained with electron microscopy and the red cell absorption technique. The elementary bodies of the virus are mainly spheres of approximately $100 \mathrm{~m} \mu$. diameter associated with a few short filaments. The virus is very similar in appearance to standard influenza strains. Pl. 1, fig. 2, shows the results obtained with the spray technique. The virus particles seen in the droplet patterns were readily removed by absorption with red cell ghosts and did not appear in the patterns sprayed after absorption.

Counts were made by the two techniques of the numbers of particles $/ \mathrm{ml}$. and these counts were related to the infectivity and haemagglutination titres. Ratios for the number of particles/agglutinating dose (particles/AD), number of minimal infective doses/agglutinating dose (ID 50/AD), and number of particles/ID 50 were calculated and are shown as logarithms (base 10) in Table 1. There was no spray count for Expt. 1 as the dialysed material had

Table 1. Ratios $\left(\log _{10}\right)$ of particles/agglutinating dose, egg infective dose/ agglutinating dose, and particles/egg infective dose for fowl plague virus

The table shows results of three separate experiments.

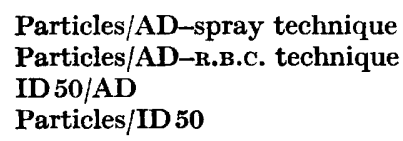

\begin{tabular}{ccc}
\multicolumn{3}{c}{ Ratio $\left(\log _{10}\right)$} \\
$7 \cdot 1$ & $6 \cdot 9$ & 6.9 \\
$6 \cdot 2$ & $6 \cdot 9$ & $7 \cdot 1$ \\
0.9 & $5 \cdot 0$ & $6 \cdot 1$ \\
& $1 \cdot 9$ & 0.9
\end{tabular}

been treated with osmic acid which made subsequent identification of particles very difficult. The type of result obtained is similar to that found previously with influenza virus strains, although the ratio of particles/ agglutinating dose is slightly lower than that of standard influenza strains. The material used in the second experiment, although harvested at $18 \mathrm{hr}$. , had an unusually low ratio of ID 50/AD. Otherwise the results as regards the ratio of particles/agglutinating dose are consistent and give an average figure of $10^{7.0}$. It seems likely that under optimal conditions there are close to 10 particles in the infective dose (ID 50).

\title{
Nervcastle disease virus
}

Pl. 1, fig. 3, shows the results obtained with electron microscopy and the red blood cell absorption technique. We found a wide variation in particle size (approximately $150-250 \mathrm{~m} \mu$. in diameter) in agreement with previous workers (Dawson \& Elford, 1949). There is some indication of internal structure after fixation with osmic acid. Pl. 1, fig. 4, shows the results obtained with the spray technique. The same wide variation in size distribution is noticed, and internal structures are quite clear. All particles identified and counted as 
virus were removed by red cell absorption. The counts and ratios obtained by the two techniques are shown in Table 2. Some difficulty was experienced with the biological tests with this virus. Infectivity titrations, carried out 2 or 3 times on each material, tended to give 'takes' over a wide range of dilutions near the end-point, suggesting considerable egg variation in the

Table 2. Ratios $\left(\log _{10}\right)$ of particles/agglutinating dose, egg infective dose/ agglutinating dose, and particles/egg infective dose for Newcastle disease virus

Three experiments.

\begin{tabular}{lccc}
\multicolumn{2}{c}{ Three experiments. } & \multicolumn{3}{c}{ Ratio $\left(\log _{10}\right)$} \\
\cline { 2 - 4 } Particles/AD-spray technique & $7 \cdot 0$ & $7 \cdot 1$ & $7 \cdot 0$ \\
Particles/AD-R.B.c. technique & $7 \cdot 0$ & $7 \cdot 1$ & $7 \cdot 2$ \\
ID50/AD & $6 \cdot 1$ & $6 \cdot 3$ & $6 \cdot 6$ \\
Particles/ID 50 & 0.9 & $0 \cdot 8$ & $0 \cdot 7$
\end{tabular}

response to infection by this virus. Also with some preparations of Newcastle disease virus there was far more variation in the results of haemagglutination titrations by the pattern method than with influenza strains; at present there is no explanation for this finding. When this difficulty was encountered it was assumed that the haemagglutination titre was too variable to use as a standard of reference. The ratios were therefore calculated where possible without including the haemagglutination titres.

The ratio of particles $/ \mathrm{AD}$ is about $10^{7 \cdot 1}$, again not greatly different from that of the influenza and fowl plague viruses. The ratio of ID 50/AD appears to be higher than in the case of influenza viruses particularly in Expt. 3. The ratio of particles/ID 50 is rather lower than for influenza virus strains, being in the range of $0.7-0.9 \log$ units, i.e. 5-7 particles. This figure is in good agreement with the calculations of Bang (1948).

\section{Mumps virus}

The particles of mumps virus could be readily counted by the spray technique. A droplet pattern containing mumps virus and polystyrene latex particles is shown in Pl. 2, fig. 5. A wide variation in diameter (approximately 100-300 m $\mu$.) may be noted (cf. Dawson \& Elford, 1949; Ray \& Swain, 1954), and there are marked indications of internal structure which appear after osmic acid fixation. Pl. 2, fig. 6, shows a sprayed droplet after 'cascade' absorption has been carried out. Only latex particles are now present.

The particle counts and ratios obtained for three experiments are shown in Table 3. The ratio of particles/agglutinating dose for mumps virus was much higher than with any of the strains hitherto described. This fact may be related to the difficulty of absorbing mumps virus with red cells. High ratios of particles/agglutinating dose were also found with influenza $\mathrm{C}$ virus which is also difficult to absorb with red cells. This point is discussed further under influenza $\mathrm{C}$ virus.

Preparations 1 and 2 showed a lower ratio of ID 50/AD than was found with most preparations of influenza virus and this finding is characteristic of mumps 
virus. The third preparation gave an unusually high ratio of ID 50/AD, although the techniques followed were not varied in the three experiments. Usually, however, mumps virus showed a low efficiency of initiating infection, some hundreds of particles/ID 50 being necessary whether titrated in the allantoic or amniotic cavity of the chick embryo.

Table 3. Ratios ( $\log _{10}$ ) of particles/agglutinating dose, egg infective dose/ agglutinating dose, and particles/egg infective dose for mumps virus

Three experiments.

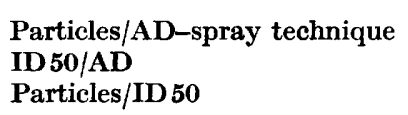

\begin{tabular}{|c|c|c|}
\hline \multicolumn{3}{|c|}{ Ratio $\left(\log _{10}\right)$} \\
\hline $7 \cdot 4$ & $7 \cdot 4$ & $7 \cdot 5$ \\
\hline $4 \cdot 5$ & 4.9 & 6.3 \\
\hline 2.9 & $2 \cdot 5$ & 1.2 \\
\hline
\end{tabular}

\section{Influenza $C$ virus}

The spray technique was found most suitable for influenza $\mathrm{C}$ virus. Pl. 2, fig. 7, shows a sprayed droplet pattern containing particles of this virus. These are spheres of approximately $100 \mathrm{~m} \mu$. diameter, but are much more flattened (they cast very short shadows in the electron microscope image) and lacking in contrast than the strains of influenza virus previously studied. Clumps of virus particles such as those shown at higher magnifications in Pl. 2, fig. 8, occurred frequently, particularly in the second experiment. 'Cascade' absorptions removed both single particles and clumps from infected fluids. Only a few filaments were seen adsorbed to red cell ghosts. Counts were made of the number of individual particles, and in addition an attempt was made to count the number of particles in the clumps wherever this was possible. Table 4 gives the results obtained. The particle counts are

Table 4. Ratios $\left(\log _{10}\right)$ of particles/agglutinating dose, egg infective dose/ agglutinating dose, and particles/egg infective dose for influenza $\mathrm{C}$ virus

\begin{tabular}{lccc} 
& \multicolumn{3}{c}{ Ratio $\left(\log _{10}\right)$} \\
Particles/AD-spray technique & $7 \cdot 4-7 \cdot 4$ & $7 \cdot 5-7 \cdot 7$ & $7 \cdot 6$ \\
ID50/AD & $5 \cdot 6$ & $5 \cdot 7$ & $6 \cdot 2$ \\
Particles/LD 50 & $\mathbf{1 \cdot 8 - 1 \cdot 9}$ & $\mathbf{1 \cdot 8 - 2 \cdot 0}$ & $\mathbf{1 \cdot 4}$
\end{tabular}

indicated in a range: in the higher figure given the particles within clumps are estimated individually, in the lower figure clumps have been counted as single 'particles'. As in the case of mumps virus the ratio of particles/agglutinating dose is higher than that of standard influenza strains. It seems likely that this high figure is a reflexion of the poor adsorption of this virus to fowl cells, as demonstrated by the need to use the 'cascade' technique to obtain efficient absorption. Thus one could visualize that at the haemagglutination end-point most of the virus particles present are not adsorbed to the fowl cells. There is no direct experimental evidence for this but the coincidence of high particle/AD ratios and poor adsorption to fowl cells found with both mumps and influenza $\mathrm{C}$ viruses is in favour of this explanation. 
The correlation coefficient between latex and virus particles in Expt. 2 was below the level of statistical significance since the correlation found might have occurred by chance in approximately one out of ten experiments. This is the least significant correlation coefficient found in all the present experiments and may be due to the complicating factor of virus clumps, as about one-third of the particles counted in this experiment occurred in clumps of 3 to 50 particles. In Expts 1 and 3 there were fewer clumps and the correlation coefficients were statistically significant.

\section{DISCUSSION}

In this and two preceding studies (Donald \& Isaacs, 1954 $a, b$ ) particle counts were made of a number of strains of haemagglutinating animal viruses, and the figures related to the agglutination titres in a pattern test with $10^{7 \cdot 1}$ to $10^{7 \cdot 2}$ red cells. The figures found have been surprisingly constant and in most cases $10^{7.1}$ to $10^{7.2}$ virus particles/agglutinating dose has been the result, i.e. about one virus particle/red cell at the agglutination end-point (cf. Werner \& Schlesinger, 1954). The exceptions found have been influenza virus filaments which gave a ratio of about $10^{6.6}$ and mumps and influenza $C$ viruses which have given ratios of $10^{7.4}$ to $10^{7 \cdot 7}$. The low ratio for influenza virus filaments means a much more efficient agglutination process than that found for spheres, and is presumably related to the greater average mass of viral haemagglutinin/ particle in filamentous strains. Thus experiments with ultrasonic vibrations showed that virus filaments contained agglutinin along their entire length (Donald \& Isaacs, 1954 $b$ ), a finding which makes it easy to understand their more efficient agglutinating behaviour. Mumps and influenza $\mathrm{C}$ viruses, on the other hand, have shown a less efficient agglutinating behaviour than standard influenza strains, and it is probably not a coincidence that these are the only two strains we have studied which were not readily absorbed by fowl red cells, but required the 'cascade' absorption technique. Presumably, at the agglutination end-point with these two strains, only a small fraction of the virus is adsorbed to the red cells.

The ratio of infective doses/agglutinating dose (ID 50/AD) with these viruses has shown far more variation in our hands. The commonest figure found has been about $10^{6.1}$ ID 50/AD, but we have recently studied one strain of influenza virus with a ratio of nearly $10^{7}$, i.e. almost every particle was infective, whereas other strains tested under identical conditions have repeatedly shown figures of about $10^{5 \cdot 0}$. With some strains of virus we have noticed big variations in this ratio in different experiments (e.g. mumps virus, Table 3). In searching for an explanation for these variations it seems important that we have used allantoic fluids from individual eggs in order to obtain the clearest fluids for electron microscopy; on the other hand, egginfectivity measurements have frequently been carried out 2 or 3 times, generally with fairly reproducible results. This suggests that variability in the ID 50/AD ratio in the same strain may be due to variations in the quality of virus produced in individual eggs, and the behaviour of individual eggs 
Journal of General Microbiology, Vol. 12, No. 2
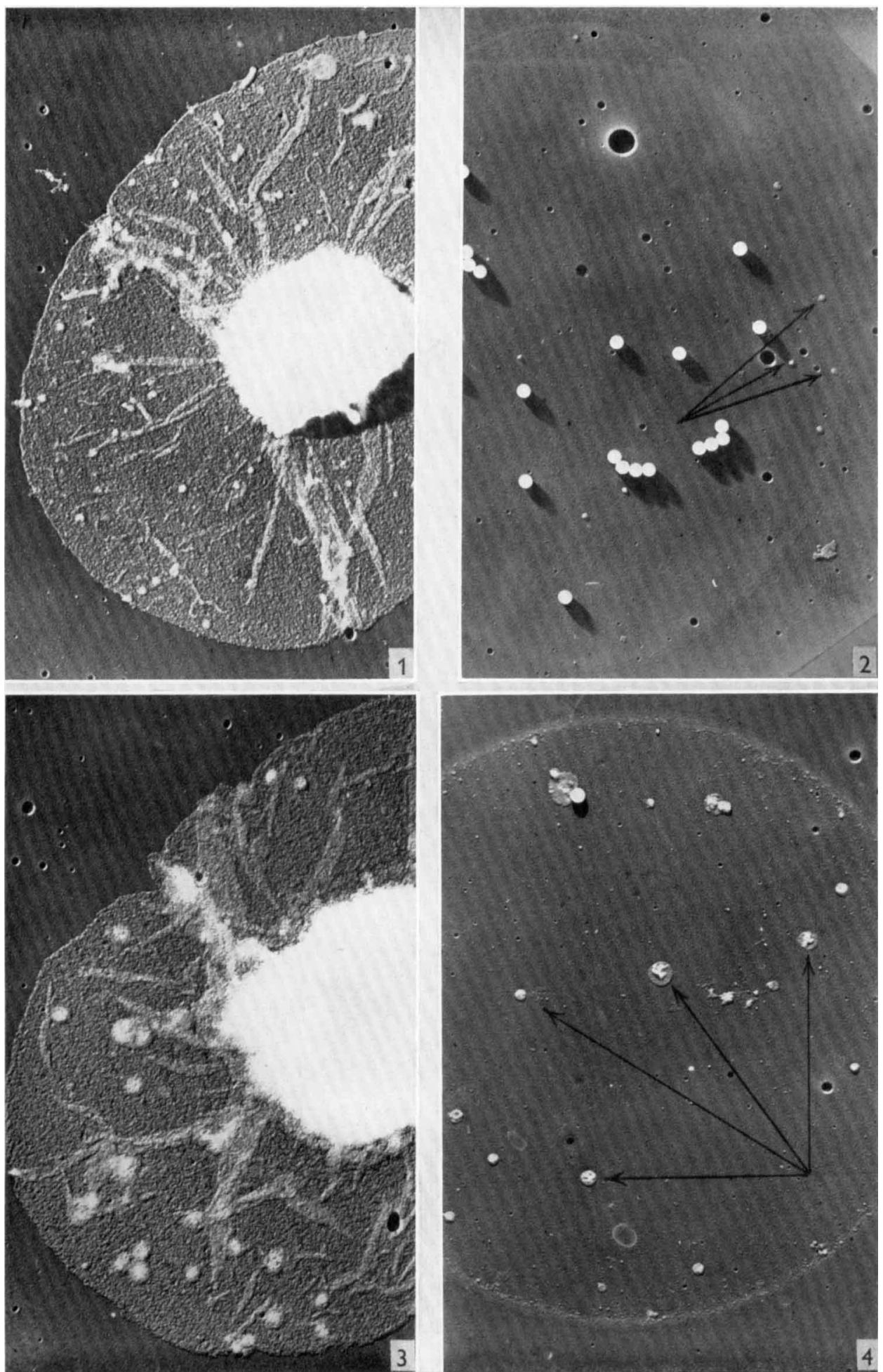

A. Isaacs \& H. B. Donald-Particle counts of hlemagglutinating viruses. Plate 1 
Journal of General Microbiology, Vol. 12, No. 2

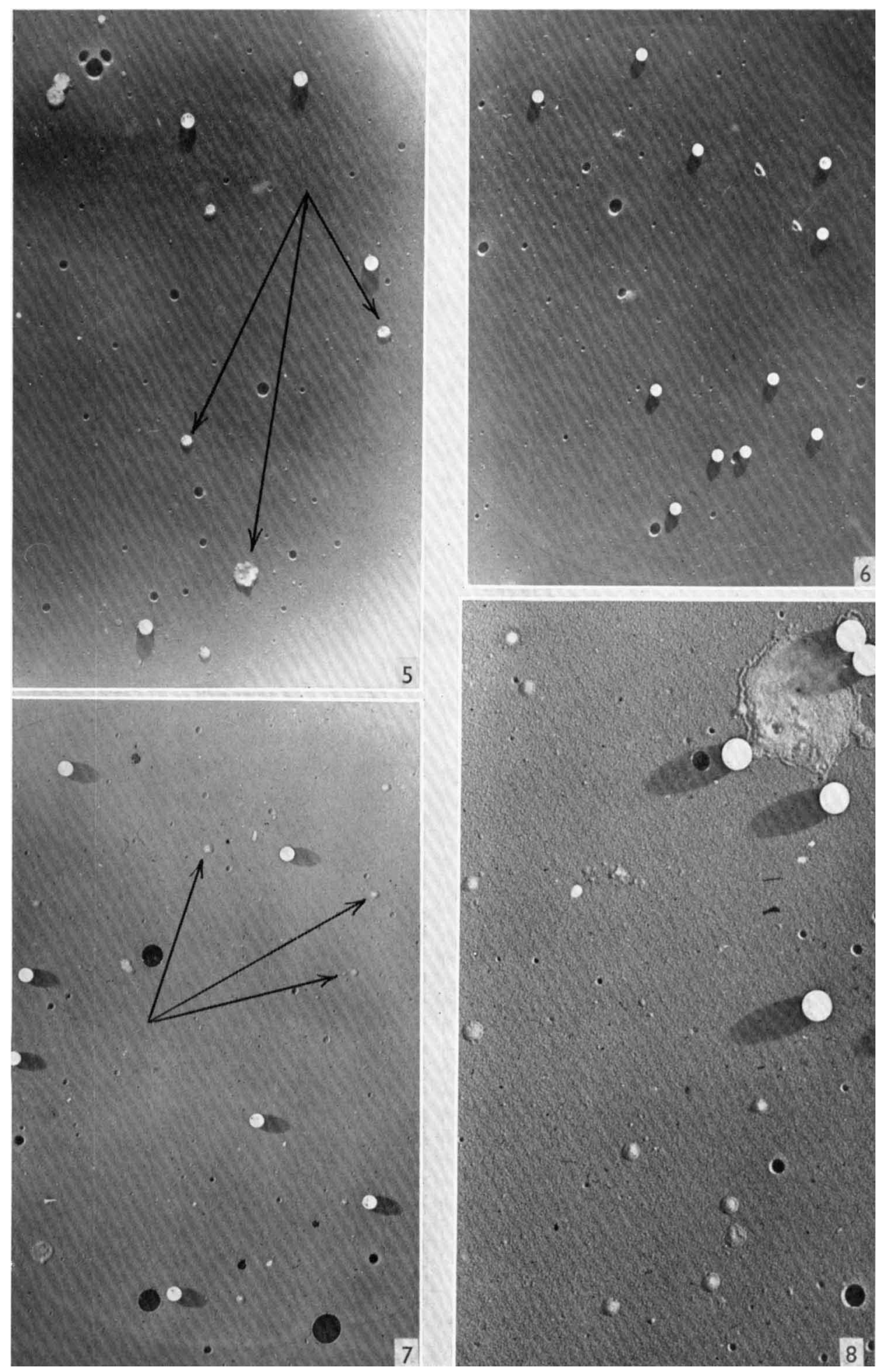

A. Isaacs \& H. B. Donald-Particle counts of haemagglutinating viruses. Plate 2 
deserves further attention in this respect. The variation in ID 50/AD ratio with different strains, and with the same strain tested on different occasions in individual eggs, may be in some way related to the phenomenon of 'incomplete' virus, described by von Magnus (1946). Our results suggest that the differences in ratio are unrelated to the number of virus particles/agglutinating dose or to the efficiency of the adsorptive and agglutinating behaviour of different virus strains.

We wish to thank Mr O. Green and Mr E. Owen for their most valuable technical assistance.

\section{REFERENCES}

Bang, F. B. (1948). Studies on Newcastle disease virus: 3. Characters of the virus itself with particular reference to electron microscopy. J. exp. Med. 88, 251.

Dawson, I. M. \& Elford, W. J. (1949). The investigation of influenza and related viruses in the electron microscope by a new technique. J.gen. Microbiol. 3, 298.

Donald, H. B. \& IsaAcs, A. (1954a). Counts of influenza virus particles. J. gen. Microbiol. 10, 457 .

Donald, H. B. \& Isaacs, A. (1954b). Some properties of influenza virus filaments shown by electron microscopic particle counts. J. gen. Microbiol. 11, 325.

Magnus, $P$. von (1946). Studies on interference in experimental influenza. 1. Biological observations. Ark. Kemi Min. Geol. $24 \mathrm{~B}, 1$.

Minuse, E., Quilligan, J. J. \& Francis, T. (1954). Type C influenza virus. 1. Studies of the virus and its distribution. J. Lab. clin. Med. 43, 31.

RAX, G. B. \& SwaIn, R. H. A. (1954). An investigation of the mumps virus by electron microscopy. J. Path. Bact. 67, 247.

TAYLOR, R. M. (1949). Studies on survival of influenza virus between epidemics and antigenic variants of the virus. Amer. J. publ. Hlth, 39, 171.

Werner, G. H. \& Schlesinger, R. W. (1954). Morphological and quantitative comparison between infectious and non-infectious forms of influenza virus. J. exp. Med. 100, 203.

\section{EXPLANATION OF PLATES}

All preparations were gold-manganin shadowed.

Pisate 1

Fig. 1. Particles of fowl plague virus absorbed on to a red cell ghost. $\times 10,000$.

Fig. 2. Part of a microdrop containing polystyrene latex and fowl plague virus particles. The small flatter particles indicated by arrows are the elementary bodies of the virus. $\times 10,000$.

Fig. 3. Particles of Newcastle disease virus absorbed on to a red cell ghost. $\times 10,000$.

Fig. 4. Part of a microdrop containing polystyrene latex and Newcastle disease virus particles. The particles indicated by arrows are the elementary bodies of the virus. $\times 10,000$.

\section{Prate 2}

Fig. 5. Part of a microdrop containing polystyrene latex and mumps virus particles. The particles indicated by arrows are the elementary bodies of the virus. $\times 10,000$.

Fig. 6. Part of a microdrop showing allantoic fluid infected with mumps virus after 'cascade' absorption with red cells. Polystyrene latex particles but no mumps virus particles present. $\times \mathbf{1 0 , 0 0 0}$.

Fig. 7. Microdrop containing polystyrene latex, and particles of influenza $\mathrm{C}$ virus indicated by arrows. $\times 10,000$.

Fig. 8. Same as fig. 7 but $\times \mathbf{2 5 , 0 0 0}$. In addition to flattened isolated particles, a clump is shown.

(Received 29 September 1954) 